\title{
Active communities and growth of soil microorganisms are framed by mean annual precipitation in three California annual grasslands
}

Megan M. Foley ${ }^{1,2}$, Steven J. Blazewicz ${ }^{3}$, Karis J. McFarlane ${ }^{3}$, Alex Greenlon ${ }^{4}$, Michaela Hayer ${ }^{1,2}$,

Jeffrey A. Kimbrel ${ }^{3}$, Benjamin J. Koch ${ }^{1,2}$, Keith Morrison $^{3}$, Ember Morrissey ${ }^{5}$, Bruce A. Hungate $^{1,2}$, Jennifer Pett-Ridge $e^{3,6}$

1. Center for Ecosystem Science and Society, Northern Arizona University, Flagstaff AZ, USA

2. Department of Biological Sciences, Northern Arizona University, Flagstaff AZ, USA

3. Physical and Life Sciences Directorate, Lawrence Livermore National Laboratory, Livermore, CA, USA

4. Department of Environmental Science, Policy, and Management, University of California, Berkeley CA, USA

5. Division of Plant and Soil Sciences, West Virginia University, Morgantown, West Virginia, USA

6. Life \& Environmental Sciences Department, University of California Merced, Merced, California, USA 


\section{Abstract}

2 Earth system models project altered precipitation regimes across much of the globe. In

3 California, the winter wet season is predicted to extend into spring, and the summer dry period to

4 lengthen. How altered precipitation will affect soil carbon (C) persistence is a key knowledge

5 gap. However, we do not have a mechanistic understanding of how altered soil moisture regimes

6 will affect microbial population dynamics. Using quantitative stable isotope probing (qSIP), we

7 compared total and active soil microbial communities across three California annual grassland

8 ecosystems that span a rainfall gradient and have developed upon similar parent material. We

9 also assessed multiple edaphic variables, including available $\mathrm{C}$ and the radiocarbon $\left({ }^{14} \mathrm{C}\right)$ age of

10 soil C. Samples were assayed in the wet season, when we expected environmental conditions

11 would be most similar across sites. We hypothesized that the long-term legacy of soil water

12 limitation would be reflected in lower community growth capacity at the driest site. We also

13 predicted that actively growing communities would be more compositionally similar across the

14 gradient than the total background microbiome. Across the three sites, edaphic parameters such

15 as $\mathrm{pH}$ roughly sorted with mean annual precipitation, and soil carbon age increased with

16 precipitation. Bacterial growth rates increased from the driest site to the intermediate site, and

17 rates were comparable between the intermediate and wettest sites. These differences were

18 persistent across major phyla, including the Actinobacteria, Bacteroidetes, and Proteobacteria.

19 Taxonomic identity was a strong predictor of growth, such that the growth rates of a taxon at one

20 site predicted its growth rates at the others. We think this fact, that taxa that grew quickly at one

21 site tended to grow quickly at the others, is likely a consequence of genetically determined

22 physiological traits, and is consistent with the idea that evolutionary history influences growth

23 rate. 


\section{Introduction}

Rainfall patterns and soil water content are ultimate controllers of microbial population

26 dynamics (growth and death) and Earth system models project major changes in the timing and

27 intensity of precipitation events globally ${ }^{1,2}$. Since microorganisms mediate a wide range of

28 ecosystem processes, understanding how a site's climate history impacts microbial communities

29 is essential. In Mediterranean climates, seasonal fluctuations between dry and wet seasons can

30 drive dramatic changes in microbial community structure and function ${ }^{3,4}$. Microorganisms

31 indigenous to these ecosystems must withstand both direct physiological stress during prolonged

32 periods of low soil moisture and be able to compete for resources when seasonal rains return and

33 plant growth resumes ${ }^{5}$.

34 Historic exposure to low soil water potential can have a lasting effect on microbial

35 respiration, enzyme activity, and carbon use efficiency ${ }^{6-8}$, and is likely to influence growth as

36 well. Repeated exposure to limited soil moisture may select for traits that confer tolerance to

37 water stress and against traits that enhance organisms' ability to grow efficiently or acquire

38 resources $^{9-11}$. If so, soil microorganisms subject to prolonged moisture deficits may grow more

39 slowly, because of ecophysiological adaptations that incur a cost to growth. For example, the

40 production of extracellular polymeric substances can be a substantial carbon sink for bacteria

41 growing under water stress while osmolyte regulation in response to water stress can consume

42 both nutrients and energy ${ }^{12,13}$. If such traits are advantageous under chronic water stress,

43 genomic and biochemical cost to maintain such systems may ensue. This, microbial taxa from

44 soils exposed to chronic water stress might be expected to grow more slowly even in the absence

45 of immediate water stress. 
Soil water dynamics also shape the structure of microbial communities ${ }^{14,15}$. Most studies

47 of soil microbial diversity rely on sequencing of total DNA, which typically includes genetic

48 material from not only active cells, but also dead and dormant microorganisms. Growing,

49 dormant, and dead microorganisms all play vital roles in soils, but those roles are distinct, so

50 distinguishing among them is important. The inability to distinguish among dead, dormant, and

51 growing microorganisms obscures ecological processes driving microbial community

52 composition. For example, compared to the total community detected through DNA sequencing,

53 active soil communities generally show a heightened sensitivity to changes in environmental

54 conditions, and active microbes in dry ecosystems appear to be more strongly influenced by

55 dynamic environmental conditions such as changes in soil water ${ }^{16,17}$. Alternatives, such as RNA-

56 based approaches to distinguish between dormant and metabolically active microorganisms, have

57 been criticized, and we still lack an understanding of the structure of microbial communities

58 exclusive of dead and dormant organisms ${ }^{18}$.

In our study, we compared total and active microbial communities and soil edaphic

characteristics across three California annual grassland ecosystems with Mediterranean-type

61 climates that span a rainfall gradient and developed upon similar parent material. First, we

62 characterized the soils to understand how diverging water regimes have shaped the

63 physiochemical environment that soil microbes experience within each ecosystem. We then

64 quantitatively analyzed patterns of microbial population growth using quantitative stable isotope

65 probing during the wet season, when soil water was not limiting. We hypothesized that growth

66 would be slowest in the driest site even when differences in soil water content were minimized,

67 reflecting the legacy cost of adaptation to limited soil moisture for microbial growth. Finally, we

68 compare the structure of communities inferred from 16S rRNA sequencing (the "total 
69 community") against the communities of growing organisms (the "growing community") at each

70 site. We hypothesized that growing communities would be compositionally more similar to each

71 other between sites than total communities, given the similarity in soil water content and plant

72 phenology during the weeks immediately preceding our sampling.

74 Materials and Methods

75 Site description and sample collection

We characterized soil chemistry and bacterial and archaeal communities in three coastal

77 California annual grasslands with Mediterranean-type climates. The sites span a significant

78 rainfall gradient ( $388 \mathrm{~mm} \mathrm{yr}^{-1}$ to $2833 \mathrm{~mm} \mathrm{yr}^{-1}$ ), yet have similar plant communities and soils

79 developed on similar parent material (sedimentary rock and coastal terraces) (Table 1). The

80 northmost site, Angelo Coast Range Reserve, lies upstream of the headwaters of the South Fork

81 Eel River where indigenous peoples including the Cahto, Pomo, Wailaki, Yuki, Weott, and

82 Sinkyone historically held territory ${ }^{19}$. Annual grasslands at Angelo intersperse mixed-oak

83 woodland and old-growth conifer forest that occur on strath terraces which formed as the Eel

84 River cut through the soft coastal sediment ${ }^{20,21}$. Hopland Research and Extension Center sits in

85 the foothills of the Mayacamas Mountains about $96 \mathrm{~km}$ south of Angelo encompassing

86 topographically rugged rangeland on territory originally occupied by the Pomo Nation. Furthest

87 south, Sedgwick Reserve spans the Santa Ynez Valley and San Rafael Mountains and is located

88 on land where the Chumash people have historically lived.

These sites developed on similarly-aged sedimentary rock of the Franciscan formation.

90 At Angelo, parent materials are comprised of argillite and sandstone interbedding and soils are

91 Ultic Haploxeralfs of the Hologan-Hollowtree-Casabonne complex ${ }^{22}$. At Hopland, soils 
92 developed on weathered sandstone and shale, as well as metamorphic schist and are Typic

93 Haploxeralfs of the Witherall-Squawrock complex ${ }^{23}$. Lastly, at Sedgwick, soils developed on

94 ancient sandstone and shale, as well as alluvium from the Paso-Robles formation, and are Pachic

95 Argixerolls belonging to the Botella series ${ }^{24}$.

96 Naturalized non-native annual grasses dominate vegetation at the three sites. Avena spp.

97 and Bromus spp. dominate at Hopland and Sedgwick ${ }^{25,26}$. Vegetation at Angelo is dominated by

98 non-native annual grasses including Aira caryophyllea, Bromus hordeaceuous, and Briza minor

99 and by annual and perennial forbs interspersed with the native perennial grass Danthonia

100 californica $20,22,27$ (Table 1). Avena spp. has also been observed at Angelo.

101 We collected soils in February-March 2018. At each site, surface vegetation was removed

102 and three replicate soil cores $(10 \mathrm{~cm} \times 5 \mathrm{~cm})$ were collected $1 \mathrm{~m}$ apart for chemical

103 characterization, radiocarbon characterization, and quantitative stable isotope probing. Soil cores

104 were transported on ice to Lawrence Livermore National Laboratory where they were

105 homogenized by hand, stones and large roots were removed, and portions were dried at room

106 temperature, stored at $4{ }^{\circ} \mathrm{C}$, or frozen at $-80^{\circ} \mathrm{C}$ for different downstream analyses. All analyses

107 reported here were conducted on surface soils $(0-10 \mathrm{~cm})$. We measured gravimetric soil water

108 content by drying soils to a constant weight at $105^{\circ} \mathrm{C}$. We retrieved daily mean air temperature

109 and total precipitation data for the thirty-day period preceding sample collection at each site.

\begin{tabular}{lccc}
\hline & $\begin{array}{c}\text { Angelo Coast Range } \\
\text { Reserve }\end{array}$ & $\begin{array}{c}\text { Hopland Research and } \\
\text { Extension Center }\end{array}$ & Sedgwick Reserve \\
\hline Location & $39^{\circ} 44.253^{`} \mathrm{~N}, 123^{\circ} 37.823^{\prime} \mathrm{W}$ & $39^{\circ} 00.106^{\prime} \mathrm{N}, 123^{\circ} 04.184^{\prime} \mathrm{W}$ & $34^{\circ} 42.697^{\prime} \mathrm{N}, 120^{\circ} 2.333^{\prime} \mathrm{W}$ \\
Elevation $(\mathrm{m})$ & 475 & 180 & 360 \\
MAT $\max / \mathrm{min}\left({ }^{\circ} \mathrm{C}\right)$ & $20 / 6$ & $23 / 7$ & $24 / 7$
\end{tabular}




\begin{tabular}{|c|c|c|c|}
\hline $\operatorname{MAP}\left(\mathrm{mm} \mathrm{yr}^{-1}\right)$ & 2160 & 956 & 383 \\
\hline Parent Material & $\begin{array}{l}\text { Argillite/Sandstone } \\
\text { interbedding }\end{array}$ & $\begin{array}{c}\text { Sandstone, Shale, Graywacke, } \\
\text { Schist }\end{array}$ & $\begin{array}{c}\text { Alluvium, Calcareous shale, } \\
\text { Acid sandstone }\end{array}$ \\
\hline Soil Order & Alfisol & Alfisol & Mollisol \\
\hline Soil Series & $\begin{array}{l}\text { Holohand-Hollowtree- } \\
\text { Casabonne complex }\end{array}$ & Witherell-Squawrock complex & Botella \\
\hline $\begin{array}{l}\text { Dominant } \\
\text { vegetation }\end{array}$ & $\begin{array}{c}\text { Aira spp., Bromus spp., } \\
\text { Briza spp. }\end{array}$ & $\begin{array}{l}\text { Avena spp., Bromus spp., } \\
\text { Erodium spp., Festuca spp. }\end{array}$ & Avena spp., Bromus spp. \\
\hline
\end{tabular}

110 Table 1 Characteristics of the California annual grasslands examined in this study.

112 Soil physical and chemical characterization

113 Soil chemical and physical characterization was conducted at the Oregon State

114 University Soil Health Laboratory. Bulk C and N concentrations were quantified by Elementar

115 Vario Macro cube elemental analyzer through dry combustion, separation of gaseous species,

116 and thermal conductivity detection. Trace elements were quantified by the Agilent 5110 ICP-

117 OES after soils were extracted with $0.002 \mathrm{M}$ Barium chloride. Soil texture was determined by the

118 hydrometer method. Soil pH was measured using a Mettler Toledo Seven Compact pH/Ion

119 meter. To measure $\mathrm{pH}, 4 \mathrm{~g}$ of soil was suspended in $8 \mathrm{~mL}$ of $0.01 \mathrm{M} \mathrm{CaCl}_{2}$ and equilibrated for 1

120 hour prior to analysis ${ }^{28}$.

121 Additional soil cores were collected from the top $5 \mathrm{~cm}$ of soil from Sedgewick, Angelo

122 and Buck field sites in June of 2019 for moisture analysis. Soil cores were also collected from

123 the top $8-15 \mathrm{~cm}$ of soil to calculate bulk density. Intact soil cores were prepared and analyzed

124 using Meter HYPROP in accordance with manufacturer's instructions. The HYPROP was used

125 to generate a partial soil moisture release curve on wet soils. Additional cores were subsampled

126 and analyzed using WP4C in accordance with manufacturer's instructions. The WP4C was used 
127 to generate a partial soil moisture release curve on dry soils. Partial soil moisture release data

128 generated by Hyprop and WP4C were used in accordance with manufacturer's instructions to

129 generate complete soil moisture release curves using Hyprop fit software.

Quantitative X-ray diffraction

Quantitative X-ray diffraction (qXRD) was performed at the Space Science and

133 Astrobiology Division at NASA's Ames Research Center. Samples for qXRD were crushed in a

134 mortar and pestle and passed through a $250 \mu \mathrm{m}$ sieve. The samples were spiked with 20 wt. \%

$135 \alpha_{\mathrm{Al}_{2} \mathrm{O}_{3}}$ (internal standard) and micronized for 5 minutes in ethanol using a McCrone mill. The

136 ground samples were then transferred to a plastic tray and dried under heat lamps. The

137 micronized samples sere then saturated with Vertrel ${ }^{\circledR}$ and vortexed with plastic beads to promote

138 random orientation of the minerals. The random powders were side loaded into XRD sample

139 mounts. All powdered samples were analyzed on a Rigaku Smartlab diffractometer using Cu k-

140 alpha radiation and a scintillation detector with $1^{\circ}$ divergence and receiving slits. The samples

141 were scanned from $5^{\circ}$ to $65^{\circ} 2 \theta$ at $0.02^{\circ}$ steps with a 2 second per step count time. Quantitative

142 mineralogy was determined using the full pattern peak-fitting program RockJock $11^{29}$.

144 Natural Abundance Stable Isotopes and Radiocarbon analysis of bulk soils and incubations

145 For each core, subsamples of dried homogenized soil were analyzed for $\delta^{13} \mathrm{C}$ and $\delta^{15} \mathrm{~N}$ at

146 the Center for Stable Isotope Biogeochemistry at the University of California, Berkeley

147 (IsoPrime100 mass spectrometer) or prepared for bulk soil radiocarbon measurement by sealed-

148 tube combustion to $\mathrm{CO}_{2}$ in the presence of $\mathrm{CuO}$ and $\mathrm{Ag}$. A subsample of fresh soil from each

149 core was incubated in the lab to measure $\Delta^{14} \mathrm{CO}_{2}$ of microbially respired carbon. Roots were 
150 removed from soils by hand picking and left undisturbed for one week at room temperature to

151 allow any remaining roots to senesce. For each core, approximately $150 \mathrm{~g}$ dry mass-equivalent

152 soil was weighed into $150 \mathrm{~mL}$ beakers and placed inside quart-sized mason jars with stopcock-

153 fitted lids. Soils were pre-incubated for one day before incubation jars were sealed and

154 headspaces flushed with $\mathrm{CO}_{2}$-free air. Soils were then incubated at room temperature until

155 enough $\mathrm{CO}_{2}$ had accumulated for ${ }^{14} \mathrm{C}$ measurement (9-11 days). At the end of the incubation

156 period, headspace $\mathrm{CO}_{2}$ was cryogenically purified for radiocarbon analysis. Aliquots of purified

$157 \mathrm{CO}_{2}$ were analyzed for $\delta^{13} \mathrm{C}$ at the UC Davis Stable Isotope Laboratory (GVI Optima Stable

158 Isotope Ratio Mass Spectrometer).

$159 \mathrm{CO}_{2}$ from both combusted bulk soil and incubation jars was purified cryogenically at the

160 Center for Accelerator Mass Spectrometry (CAMS) at Lawrence Livermore National Laboratory

161 using a vacuum line before being reduced to graphite on iron powder in the presence of $\mathrm{H}_{2}$

162 (Vogel et al., 1984). Radiocarbon abundance in graphitized samples was determined on the FN

163 Van de Graaff Accelerator Mass Spectrometer at Lawrence Livermore National Laboratory’s

164 Center for Accelerator Mass Spectrometer. Radiocarbon values are reported in $\Delta^{14} \mathrm{C}$ notation

165 corrected for mass-dependent fractionation using measured $\delta^{13} \mathrm{C}$ values ${ }^{30}$.

$167{ }^{18} \mathrm{O}$-water quantitative stable isotope probing (qSIP)

169 flatbottom vials. Soils were dried in a laminar flow hood at room temperature for 24 hours prior

170 to isotope addition. One milliliter of isotopically enriched water $\left(98.15\right.$ at $\left.\%{ }^{18} \mathrm{O}-\mathrm{H}_{2} \mathrm{O}\right)$ or natural

171 abundance water (as a control) was pipetted onto the soil slowly and evenly and gently mixed

172 with the pipette tip. After the water addition, vials were immediately sealed inside $500 \mathrm{ml}$ mason 
173 jars and incubated at room temperature in the dark for 8 days. At the end of the incubation, soils

174 were frozen in liquid nitrogen and then stored at $-80^{\circ} \mathrm{C}$.

175 DNA was extracted from all soil samples using a modified protocol adapted from

176 Barnard $(2015)^{3}$. Three replicate extractions were conducted for each sample and then replicate

177 DNA extracts were combined. For each extraction, soil $(0.4 \mathrm{~g}+/-0.001)$ was added to $2 \mathrm{ml}$

178 Lysing Matrix E tube (MP Biomedicals) and extracted twice as follows. $500 \mu$ l extraction buffer

179 (5\% CTAB, 0.5 M NaCl, $240 \mathrm{mM} \mathrm{K}_{2} \mathrm{HPO}_{4}, \mathrm{pH}$ 8.0) and $500 \mu \mathrm{l}$ 25:24:1

180 phenol:chloroform:isoamyl alcohol were added before shaking (FastPrep24, MP Biomedicals: 30

$\left.181 \mathrm{~s}, 5.5 \mathrm{~m}^{\mathrm{s}-1}\right)$. After centrifugation $(16,100 \mathrm{x} \mathrm{g}, 5 \mathrm{~min})$, residual phenol was removed using pre-

182 spun $2 \mathrm{ml}$ Phase Lock Gel tubes (5 Prime, Gaithersburg, MD, USA) with an equal volume of

183 24:1 chloroform:isoamyl alcohol, mixed and centrifuged (16,100 x g, 2 min). The aqueous

184 phases from both extractions were pooled, mixed with $7 \mu 1$ RNAase $(10 \mathrm{mg} / \mathrm{ml})$, mixed by

185 inverting, and incubated at $50{ }^{\circ} \mathrm{C}$ for $10 \mathrm{~min} .335 \mu \mathrm{L} 7.5 \mathrm{M} \mathrm{NH} 4+$ acetate was added, mixed by

186 inverting, incubated $\left(4^{\circ} \mathrm{C}, 1 \mathrm{~h}\right)$. and centrifuged $(16,100 \mathrm{x} \mathrm{g}, 15 \mathrm{~min}$. Supernatant was

187 transferred to a new $1.7 \mathrm{ml}$ tube and $1 \mu \mathrm{l}$ Glycoblue $(15 \mathrm{mg} / \mathrm{ml})$ and $1 \mathrm{ml}$ 40\% PEG 6000 in 1.6

$188 \mathrm{M} \mathrm{NaCl}$ were added, mixed by vortex, and incubated at room temperature in the dark $(2 \mathrm{~h})$.

189 After centrifugation (16,100 x g, $20 \mathrm{~min})$, the pellet was rinsed with $1 \mathrm{ml}$ ice-cold $70 \%$ ethanol,

190 air-dried, resuspended in $30 \mu 11 \times \mathrm{TE}$ and stored at $-80^{\circ} \mathrm{C}$.

191 Samples were subjected to a cesium chloride density gradient formed by physical density

192 separation via ultracentrifugation as previously described with minor modifications ${ }^{31,32}$. For each

193 sample, $5 \mu \mathrm{g}$ of DNA in $150 \mu \mathrm{L} \mathrm{1xTE}$ was mixed with $1.00 \mathrm{~mL}$ gradient buffer, and $4.60 \mathrm{~mL}$

$194 \mathrm{CsCl}$ stock $\left(1.885 \mathrm{~g} \mathrm{~mL}^{-1}\right)$ with a final average density of $1.730 \mathrm{~g} \mathrm{~mL}^{-1}$. Samples were loaded

195 into $5.2 \mathrm{~mL}$ ultracentrifuge tubes and spun at $20^{\circ} \mathrm{C}$ for 108 hours at $176,284 \mathrm{RCF}_{\text {avg }}$ in a 
Beckman Coulter Optima XE-90 ultracentrifuge using a VTi65.2 rotor. Automated sample

197 fractionation was performed using Lawrence Livermore National Laboratory's high-throughput

198 SIP pipeline, which automates fractionation and clean-up tasks for the density gradient SIP

199 protocol. Ultracentrifuge tube contents were fractionated into 36 fractions $(\sim 200 \mu \mathrm{L}$ each $)$ using

200 an Agilent Technologies 1260 isocratic pump delivering water at $0.25 \mathrm{~mL} \mathrm{~min}^{-1}$ through a $25 \mathrm{G}$

201 needle inserted through the top of the ultracentrifuge tube. Each tube was mounted in a Beckman

202 Coulter fraction recovery system with a side port needle inserted through the bottom. The side

203 port needle was routed to an Agilent 1260 Infinity fraction collector. Fractions were collected in

204 96-well deep well plates. The density of each fraction was then measured using a Reichart

205 AR200 digital refractometer fitted with a prism covering to facilitate measurement from $5 \mu \mathrm{L}$, as

206 previously described ${ }^{33}$. We purified and concentrated DNA in each fraction using a Hamilton

207 Microlab Star liquid handling system programmed to automate previously described

208 glycogen/PEG precipitations ${ }^{34}$. Washed DNA pellets were suspended in $40 \mu \mathrm{L}$ of $1 \mathrm{xTE}$ and the

209 DNA concentration of each fraction was quantified using a PicoGreen fluorescence assay. The

210 fractions for each sample were binned into 9 groups based on density $(1.6900-1.7099 \mathrm{~g} / \mathrm{ml}$,

$211 \quad 1.7100-1.7149 \mathrm{~g} / \mathrm{ml}, 1.7150-1.7199 \mathrm{~g} / \mathrm{ml}, 1.7200-1.7249 \mathrm{~g} / \mathrm{ml}, 1.7250-1.7299 \mathrm{~g} / \mathrm{ml}, 1.7300-$

$2121.7349 \mathrm{~g} / \mathrm{ml}, 1.7350-1.7399 \mathrm{~g} / \mathrm{ml}, 1.7400-1.7468 \mathrm{~g} / \mathrm{ml}, 1.7469-1.7720 \mathrm{~g} / \mathrm{ml})$, and fractions within

213 a binned group were combined and sequenced.

214 For 16S rRNA gene amplicon sequencing, non-fractionated DNA as well as density

215 fractionated DNA was amplified in triplicate 10 - $\mathrm{uL}$ reactions using primers $515 \mathrm{~F}$ and $806 \mathrm{R}^{35,36}$.

216 Each reaction contained 1uL sample and 9uL of Phusion Hot Start II High Fidelity master mix

217 (Thermo Fisher Scientific) including $1.5 \mathrm{mM}$ additional $\mathrm{MgCl}_{2}$. PCR conditions were $95 \mathrm{C}$ for 2

$218 \mathrm{~min}$ followed by 20 cycles of $95 \mathrm{C}$ for $30 \mathrm{~S}, 64.5 \mathrm{C}$ for $30 \mathrm{~S}$, and $72 \mathrm{C}$ for $1 \mathrm{~min}$. The triplicate 
219 PCR products were then pooled and diluted 10X and used as a template in a subsequent dual

220 indexing reaction that used the same primers including the Illumina flowcell adaptor sequences

221 and 8-nucleotide Golay barcodes (15 cycles identical to initial amplification conditions).

222 Resulting amplicons were purified with AMPure XP magnetic beads (Beckman Coulter) and

223 quantified with a PicoGreen assay on a BioTek Synergy HT plate reader. Samples were pooled at

224 equivalent concentrations, purified with the AMPure XP beads, and quantified using the KAPA

225 Sybr Fast qPCR kit (Kapa Biosciences). A total of 9 unfractionated, and 162 fraction libraries

226 were sequenced on an Illumina MiSeq instrument at Northern Arizona University’s Genetics

227 Core Facility using a 300-cycle v2 reagent kit.

228 Paired-end $151 \mathrm{nt}$ reads were filtered to remove phiX and other contaminants with bbduk

$229 \mathrm{v} 38.56$ (default settings except $\mathrm{k}=31$ and hdist=1) ${ }^{37}$. Fastq files were then filtered/trimmed for

230 quality (maxEE=5, truncQ=2) and used to generate amplicon sequence variants (ASVs) with

231 DADA2 v1.10 and phyloseq v1.26 38,39 . Chimeric sequences were determined and removed using

232 removeBimeraDenovo from DADA2. ASV taxonomy was determined using the RDP 16S rRNA

233 gene database (training set 16) using RDP classifier v2.11, keeping classifications with greater

234 than $50 \%$ confidence $^{40}$. A phylogenetic tree was built using Muscle v3.8.31 and FastTree

$235 \mathrm{v} 2 \cdot 1 \cdot 10^{41,42}$.

237 Quantitative stable isotope probing analysis

238 Quantitative stable isotope probing (qSIP) measures the change in buoyant density of a

239 taxon's DNA, or segment of DNA, due to assimilation of a substrate-derived heavy isotope. This

240 shift in buoyant density is measured as the difference in a taxon's weighted average density in a

$241 \mathrm{CsCl}$ gradient between the control and isotope addition treatment and is used to estimate the 
242 isotopic enrichment of DNA based on a measured relationship between molecular weight of

243 DNA and isotopic enrichment.

244 We quantified excess atom fraction (EAF) ${ }^{18} \mathrm{O}$ of bacterial DNA following a modified

245 version of the procedure described by Hungate et al. using average DNA concentration to

246 normalize the relative abundance of taxa within each density fraction ${ }^{32,43,44}$. We calculated

247 median values and $95 \%$ confidence intervals for EAF ${ }^{18} \mathrm{O}$ by bootstrapping $(\mathrm{n}=1000)$ across

248 experimental replicates. qSIP analysis was limited to taxa that occurred in at least 2 (of 3)

249 experimental replicates and in at least 2 (of 9) density fractions. These criteria were chosen to

250 reduce the likelihood of falsely interpreting spurious density shifts as growth. Technical error

251 associated with tube-level differences in $\mathrm{CsCl}$ density gradients was corrected as previously

252 described ${ }^{45}$. When comparing values of ${ }^{18} \mathrm{O}$ enrichment between sites, we used fraction of

253 maximum potential enrichment (FME) ${ }^{18} \mathrm{O}$ to account for small differences in the enrichment of

254 the soil water during incubation. We computed FME ${ }^{18} \mathrm{O}$ for each taxon as EAF ${ }^{18} \mathrm{O}$ divided by

255 enrichment of the soil water.

256 For all analyses, 'growing' microbial taxa were identified as ASVs having 95\%

257 confidence intervals for EAF ${ }^{18} \mathrm{O}$ exceeding zero. We refer to the community of growing

258 microbial taxa at each site as the "growing microbial community". We refer to the microbial

259 community inferred from 16S rRNA marker gene sequencing of non-fractionated DNA at each

260 site as the "total microbial community".

Statistical analyses

All statistical analyses were conducted in R (R Core Team, 2021). Soil properties (total C

264 and N, trace elements, and texture), stable isotopes, and bulk and respired soil radiocarbon values 
were compared between sites using one-way ANOVA and Fisher's LSD test. We used one-way ANOVA and Fisher's LSD to test for differences between sites in community and phylum mean FME ${ }^{18} \mathrm{O}$ and only included taxa that were identified as growing at each site in this analysis. We also compared FME ${ }^{18} \mathrm{O}$ of taxa that were growing at Sedgwick only to the FME ${ }^{18} \mathrm{O}$ of taxa that were growing at Sedgwick and at least one other site using a t-test. We used linear regression to assess the relationship of taxon-specific FME ${ }^{18} \mathrm{O}$ between sites and included only individual ASVs that were co-occurring in at least two sites. organisms resembled each other more than would be expected by chance alone ${ }^{1}$. Phylogeny was

274 built using the SILVA v128 tree using SATé-enabled phylogenetic placement (SEPP) ${ }^{48,49}$. We

275 measured Blomberg's K and Pagel's $\lambda$ using phytools (Revell, 2012) for taxon-specific EAF ${ }^{18} \mathrm{O}$

276 values within each site and included all taxa in this analysis.

278 unfractionated DNA samples. The relative abundances of taxa in growing communities were

279 computed by removing counts from taxa that were not identified as growing via qSIP from

280 unfractionated DNA samples and then re-computing relative abundance.

We used Bray-Curtis dissimilarity to assess between-site dissimilarity for both growing

282 and total communities with vegan: Community Ecology Package (Wagner et al. 2019); principal

283 components analysis (PCA) was used to visualize community structure. We tested for

284 differences in community composition between sites using ANOSIM on ranked Bray-Curtis

285 dissimilarities. To test if the degree of community dissimilarity between sites differed for total

286 versus growing microbial communities, we performed a t-test on mean Bray-Curtis dissimilarity

287 for each pairwise comparison of sites between total and growing communities. 


\section{Results}

\section{Diverging moisture regimes at the grassland sites}

Mean annual precipitation decreases and temperature increases between Angelo, the

292 northmost site, and Sedgwick, the southmost site and Hopland experiences rainfall and

293 temperatures intermediate to these two (Table 1). In the calendar year prior to sample collection,

294 the wet season at Angelo and Hopland lasted until April, precipitation remained scarce or absent

295 during the summer months, and returned again by November. In contrast, the wet season at

296 Sedgwick occurred in January and February and didn't return until the following January

297 (Supplementary Figure 1). Total rainfall was above average at Angelo and Sedgwick and below

298 average at Hopland but overall, precipitation and temperature patterns for the year preceding

299 sampling were similar to what we expected based on long-term site level averages; Angelo was

300 the wettest and coldest site and Sedgwick was hottest and driest (Supplementary Table 1). We

301 obtained samples for this study in early 2018 during the wet season when the differences in soil

302 moisture between our sites was minimized. During the 30 days leading up to sample collection,

303 total precipitation differed between our sites by an average of $46 \mathrm{~mm}$ and soil moisture upon

304 collection from the field varied only modestly from $17 \%$ to $25 \%$ (Supplementary Tables $1 \& 2$ ).

Soil characterization

Soils at the three grassland sites developed on ancient sedimentary rock, primarily

308 sandstones and shale. At Angelo and Hopland, the wet and intermediate sites, soils are Alfisols

309 and those at Sedgwick, the driest site, are Mollisols indicating intermediate degrees of

310 weathering and soil development at the three sites. Quantitative XRD analysis showed the sites 
311 had a similar composition of minerals with modest variation in their proportions, pointing to

312 shared characteristics of soil parent material and diverging weathering regimes (Supplementary

313 Table 3). Quartz and feldspars dominated the non-clay minerals at all site and clay minerals

314 included kaolinite, chlorite, and muscovite.

315 In terms of texture, Sedgwick contained the highest proportion of clays (Table 2). This

316 variation in clay content likely contributes to differences in water retention curves, which

317 showed Sedgwick experienced lower soil water potentials at higher moisture contents than the

318 intermediate and wet sites (Supplementary Figure 1). Soil carbon and nitrogen were low at all

319 sites and exhibited little variation. $\mathrm{pH}$ decreased with increasing MAP, likely driven by increased

320 leaching of base cations with higher amounts of precipitation ${ }^{50}$. Effective cation exchange

321 capacity and most trace elements were highest in Sedgwick, with the exception of aluminum

322 which was highest in Angelo (Table 2).

323

\begin{tabular}{lcccc}
\hline & $\begin{array}{c}\text { Angelo } \\
\text { Avg } \pm \text { SE }\end{array}$ & $\begin{array}{c}\text { Hopland } \\
\text { Avg } \pm \text { SE }\end{array}$ & $\begin{array}{c}\text { Sedgwick } \\
\text { Avg } \pm \text { SE }\end{array}$ & $\begin{array}{c}\text { ANOVA } \\
\boldsymbol{P}\end{array}$ \\
\hline$\delta^{13}$ C Bulk Soil (\%) & $-27.54 \pm 0.10$ & $-27.64 \pm 0.12$ & $-26.99 \pm 0.19$ & $\mathbf{0 . 0 4}$ \\
$\delta^{15} \mathrm{~N}$ Bulk Soil (\%) & $3.75 \pm 0.36$ & $4.23 \pm 0.28$ & $4.85 \pm 0.21$ & 0.10 \\
& & & & \\
$\mathrm{pH}$ & $5.02 \pm 0.02$ & $5.55 \pm 0.03$ & $6.99 \pm 0.03$ & $<\mathbf{0 . 0 0 0 1}$ \\
ECEC (meq kg ${ }^{-1}$ soil) & $10.99 \pm 0.41$ & $10.84 \pm 0.39$ & $27.61 \pm 0.50$ & $<\mathbf{0 . 0 0 0 1}$ \\
\% Sand & $28 \pm 1.53$ & $45 \pm 1.16$ & $38 \pm 0.88$ & $<\mathbf{0 . 0 0 0 1}$ \\
\% Silt & $42 \pm 1.15$ & $36 \pm 0.58$ & $28 \pm 2.08$ & $<\mathbf{0 . 0 0 0 1}$ \\
& & & & \\
\% Clay & $27 \pm 0.88$ & $19 \pm 1.00$ & $34 \pm 0.33$ & $<\mathbf{0 . 0 0 0 1}$ \\
\% C & $1.66 \pm 0.31$ & $1.39 \pm 0.18$ & $1.99 \pm 0.08$ & 0.22
\end{tabular}




$\begin{array}{lrccc}\text { \% N } & 0.13 \pm 0.02 & 0.11 \pm 0.01 & 0.18 \pm 0.01 & \mathbf{0 . 0 3} \\ \mathrm{Al}\left(\mathrm{mg} \mathrm{kg}^{-1}\right) & 44.77 \pm 1.06 & 5.17 \pm 0.36 & B D L & <\mathbf{0 . 0 0 0 1} \\ \mathrm{Ca}\left(\mathrm{mg} \mathrm{kg}^{-1}\right) & 1455.44 \pm 52.97 & 1350.63 \pm 47.62 & 2380.67 \pm 50.32 & <\mathbf{0 . 0 0 0 1} \\ \mathrm{K}\left(\mathrm{mg} \mathrm{kg}^{-1}\right) & 98.98 \pm 6.34 & 114.92 \pm 13.91 & 390.39 \pm 29.41 & <\mathbf{0 . 0 0 0 1} \\ & & & & \\ \mathrm{Mg}\left(\mathrm{mg} \mathrm{kg}^{-1}\right) & 353.39 \pm 17.97 & 448.75 \pm 14.92 & 1760.32 \pm 38.34 & <\mathbf{0 . 0 0 0 1} \\ \mathrm{Na}\left(\mathrm{mg} \mathrm{kg}^{-1}\right) & 3.44 \pm 1.24 & B D L & 7.21 \pm 1.16 & \mathbf{0 . 0 3}\end{array}$

Table 2 Soil physical and chemical characteristics of Angelo, Hopland, and Sedgwick (mean \pm standard error, $n=3$ ). Differences between grassland means were assessed by one-way ANOVAs and Fisher's LSD. Bold text indicates P-values less than 0.05, and BDL signifies values below detection limit.

331 indicating that the average age of bulk soil $\mathrm{C}$ is oldest in the site with the highest annual rainfall

332 (Figure 1). Bulk soil $\Delta^{14} \mathrm{C}$ values were above modern at Sedgwick, indicating the presence of

333 carbon associated with atmospheric weapons testing in the $20^{\text {th }}$ century, while the more depleted

$334 \quad \Delta^{14} \mathrm{C}$ values observed for soils from Angelo suggest older and more slowly cycling soil $\mathrm{C}$ at this

335 site compared to the other sites, and our intermediate Hopland site falls between these two

336 extremes. For reference, turnover times determined using a single-pool, steady-state,

337 homogenous model suggest turnover times of approximately 200, 400, and 700 years for

338 Sedgwick, Hopland, and Angelo, respectively. In contrast, the $\Delta^{14} \mathrm{C}$ of respired $\mathrm{CO}_{2}$ was similar

339 for all soils, and indicated that microorganisms uniformly respired recently fixed C (with an

340 average age of 7 years), despite differences in the average age of bulk soil carbon. The 
341 cumulative effect of diverging precipitation regimes is apparent in bulk soil radiocarbon data,

342 where higher amounts of rainfall appear to support SOM persistence.

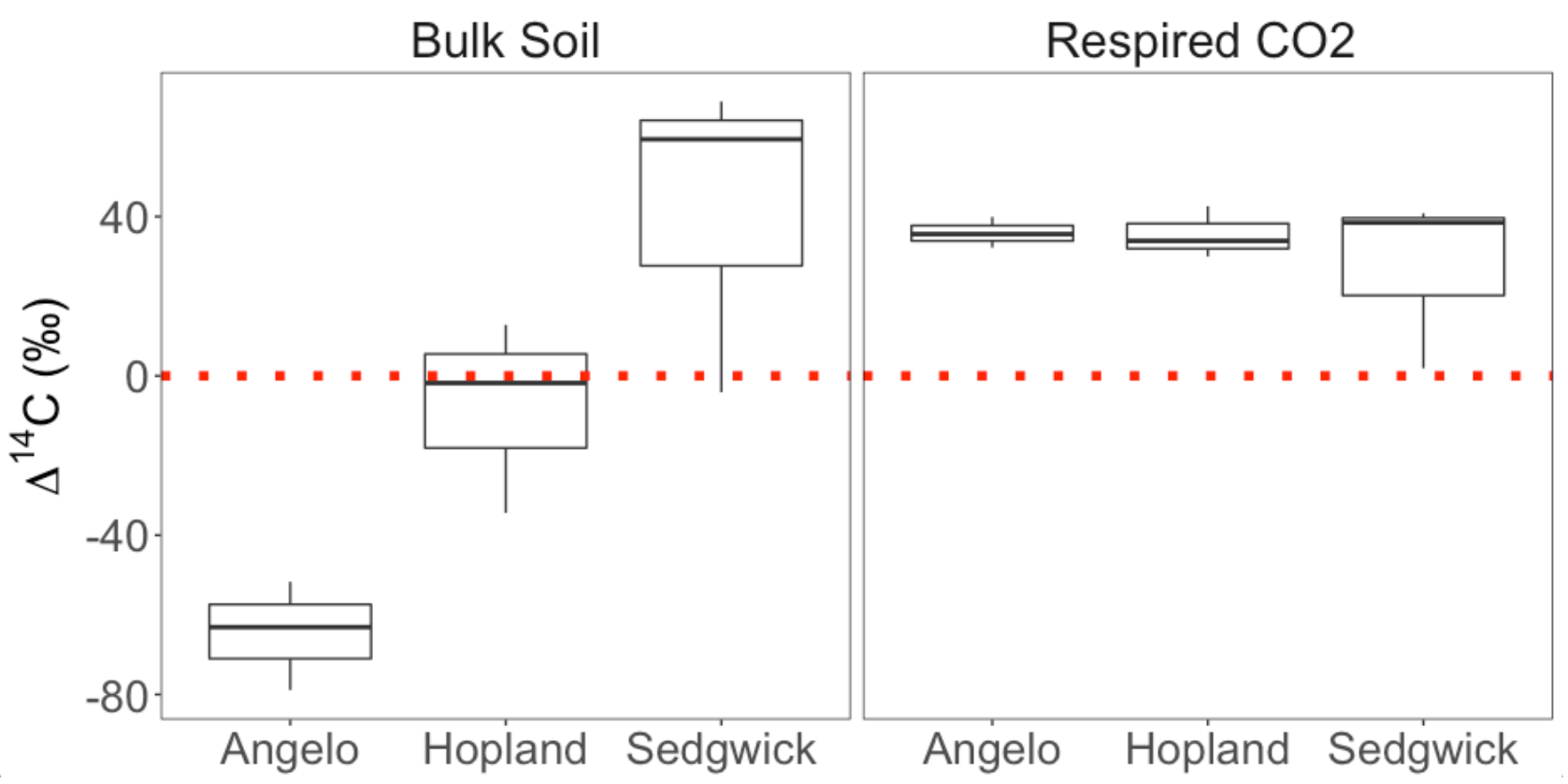

345 Figure $1 \Delta^{14} \mathrm{C}(\%)$ of bulk soil and respired $\mathrm{CO}_{2}$. The horizontal line represents atmospheric $\Delta^{14} \mathrm{C}$ 346 in 2018 and serves as a reference for post-bomb enrichment. Differences between grassland means 347 were assessed by one-way ANOVAs and Fisher's LSD. $\Delta^{14} \mathrm{C}(\%)$ of bulk soils differed between 348 sites $\left(\mathrm{p}<0.05\right.$, Fisher's LSD). $\Delta^{14} \mathrm{C}(\%)$ of respired $\mathrm{CO} 2$ did not differ between sites $(\mathrm{p}>0.05$, 349 Fisher's LSD).

\section{Microbial community structure and growth}

Community structure differed by site for both the total and growing bacterial

353 communities (Figure 2). Structure of the total and growing communities at Sedgwick were the

354 most dissimilar from the other sites, as quantified by mean pairwise Bray-Curtis Dissimilarity

355 (Figure 3). Bray-Curtis dissimilarity was statistically indistinguishable between the total and

356 growing microbial communities for each pairwise comparison of community structure between 357 sites Figure 3). 
More than $70 \%$ of $16 \mathrm{~S}$ rRNA gene sequences at each site could be attributed to three bacterial phyla: Acidobacteria, Actinobacteria (dominant orders Rubrobacterales, and Solirubrobacterales), and Proteobacteria (dominant orders Burkholderiales, Sphingomonadales, and Rhizobiales). These phyla dominated growing communities as well, comprising more than $80 \%$ of all bacterial $16 \mathrm{~S}$ rRNA gene sequences that were detected by qSIP as growing at each

363 site and accounting for at least $79 \%$ of cumulative ${ }^{18} \mathrm{O}$ assimilation in each site (Supplementary

364 Figure 3). While these phyla accounted for a large proportion of total growth, importantly, there

365 was no detectable relationship between the relative abundance of an individual taxon and its

366 growth, meaning low abundance taxa can exhibit fast growth (Supplementary Figure 4).

Figure 2 PCoA of Bray-Curtis dissimilarities for total and growing microbial communities. Community composition varies by site for the total microbial communities (ANOSIM, $p=0.0037$ )

Total Bacterial Communities

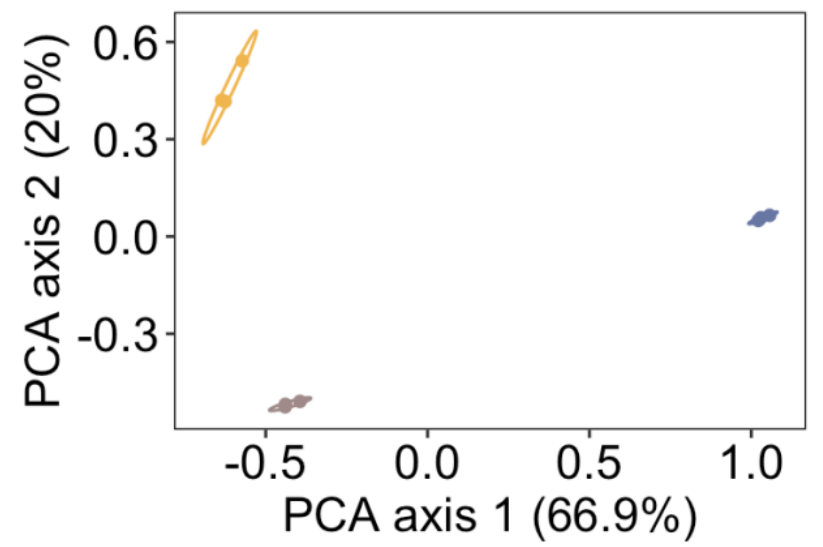

Growing Bacterial Communities

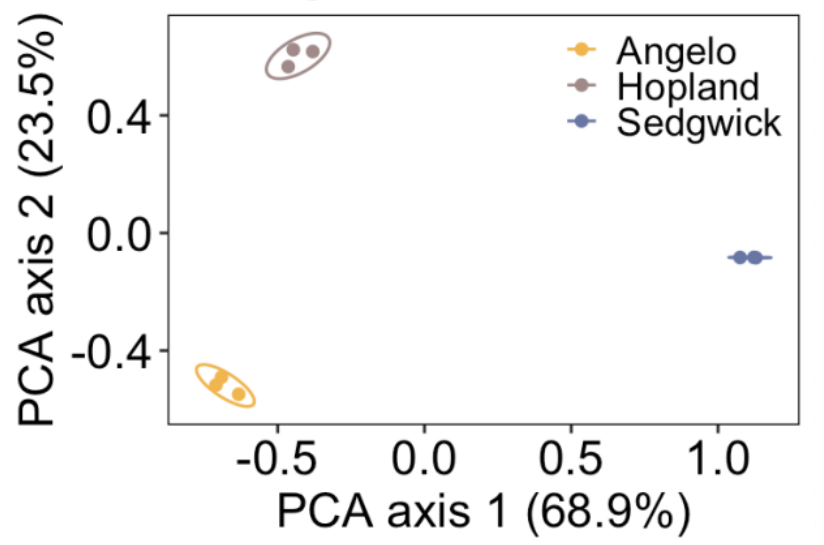




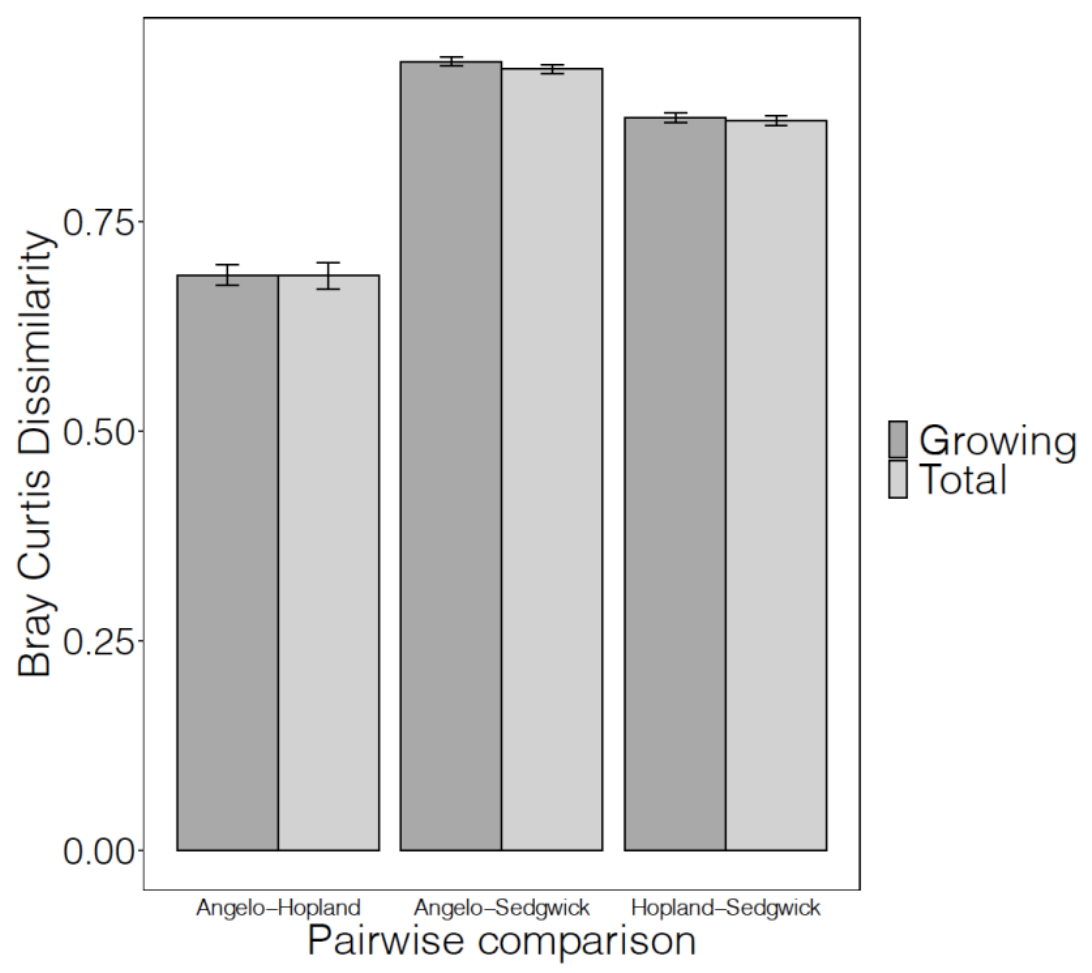

Figure 3 Shows mean pairwise dissimilarity between sites for the present microbial community and growing microbial community. Dissimilarity did not differ for growing versus total communities when comparing between Angelo and Hopland (t-test, $\mathrm{p}=0.95$ ), Angelo and Sedgwick (t-test, $\mathrm{p}=0.1699$ ), nor Hopland and Sedgwick(t-test, $\mathrm{p}=0.6453$ ). Bars show 95\% confidence intervals for the means.

Site specific variation in microbial growth was present at the community and phylum levels. Community mean FME ${ }^{18} \mathrm{O}$ was higher in Hopland and Angelo soils than in Sedgwick soils (Figure 4, $\mathrm{p}<0.001$ ). These patterns, in general, persisted across phyla: Actinobacteria and Bacteroidetes had a higher phylum mean FME ${ }^{18} \mathrm{O}$ in Hopland soils than in Sedgwick soils, and FME ${ }^{18} \mathrm{O}$ was higher in both Angelo and Hopland soils than in Sedgwick soils for the phyla Acidobacteria, Gemmatimonadetes, and Proteobacteria (Figure 4, $p<0.01$ ). We quantified the percent change in growth for microbial families that were present in Sedgwick and at least one other site and only eight families total (out of 51) exhibited more growth in Sedgwick soils: 
391 Cystobaceraceae, Thermomonosporaceae, Thermoleophilaceae, Rubrobacteraceae,

392 Comamonadaseae, Geminicoccus, Solirubrobacteraceae, and Micromonosporaceae.

For taxa that occurred at more than one site and had detectable growth, their growth rate

394 at one site was predictive of growth rates in another site (Figure 5). We compared ${ }^{18} \mathrm{O}$

395 enrichment of bacterial ASVs that were present and growing in at least two sites and found

396 positive, linear correlations of taxon-specific enrichment between sites. The growth rate of a

397 bacterial taxon in one site explained as much as $57 \%$ of the variation in that taxon's growth rate

398 in another site (Supplementary Table 4). The amount of variation explained by each regression

399 decreases as compositional dissimilarity increased (Supplementary Table 4).

We compared the growth of microorganisms at Sedgwick by grouping taxa according to

401 whether they grew at Sedgwick alone or in at least one other site. We found that taxa that were

402 unique to Sedgwick were slower growing than taxa that were growing in at least one other site

403 (Supplementary Figure 5).
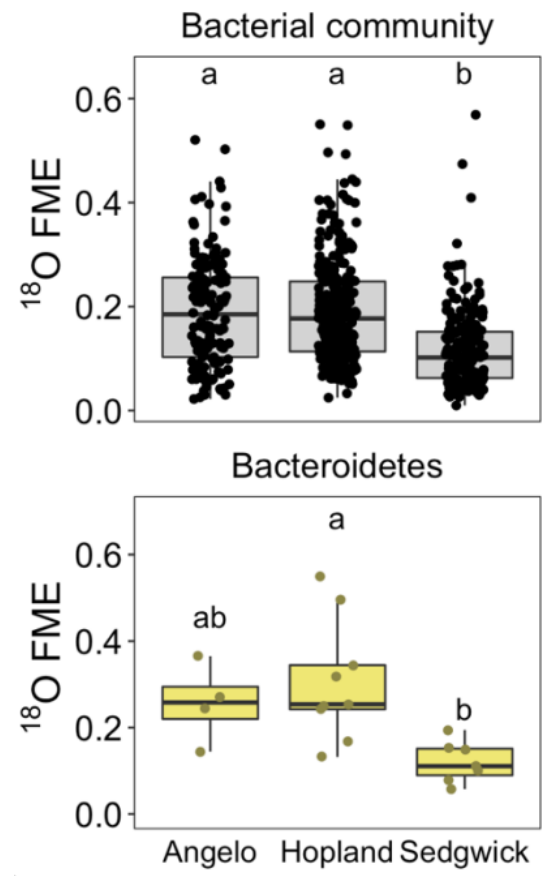
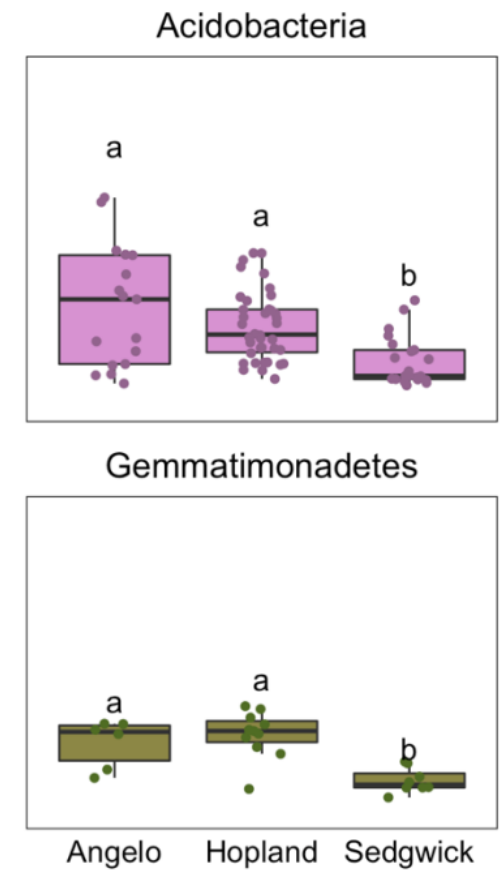

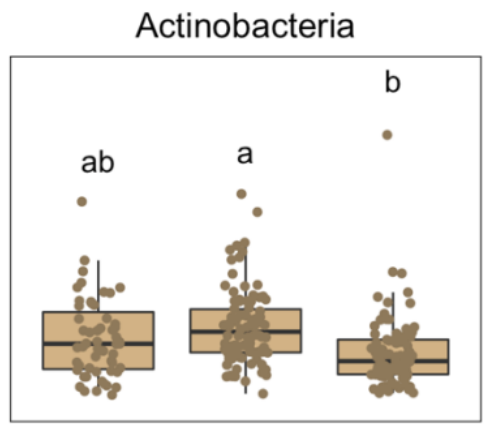

Proteobacteria

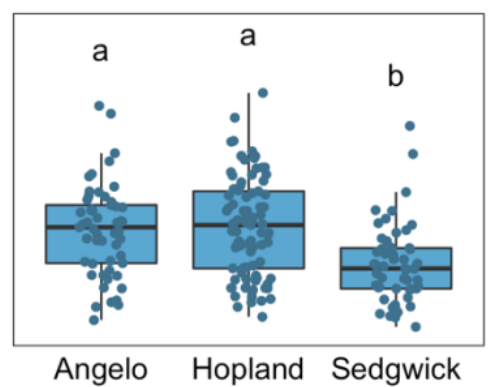


Figure 4 Community and phylum mean FME ${ }^{18} \mathrm{O}$ of microbial taxa that are growing $(95 \%$ C.I. EAF ${ }^{18} \mathrm{O}>0$ ) at each grassland site. Letters indicate significant differences between sites $(\mathrm{p}<0.05$, Fisher's LSD).
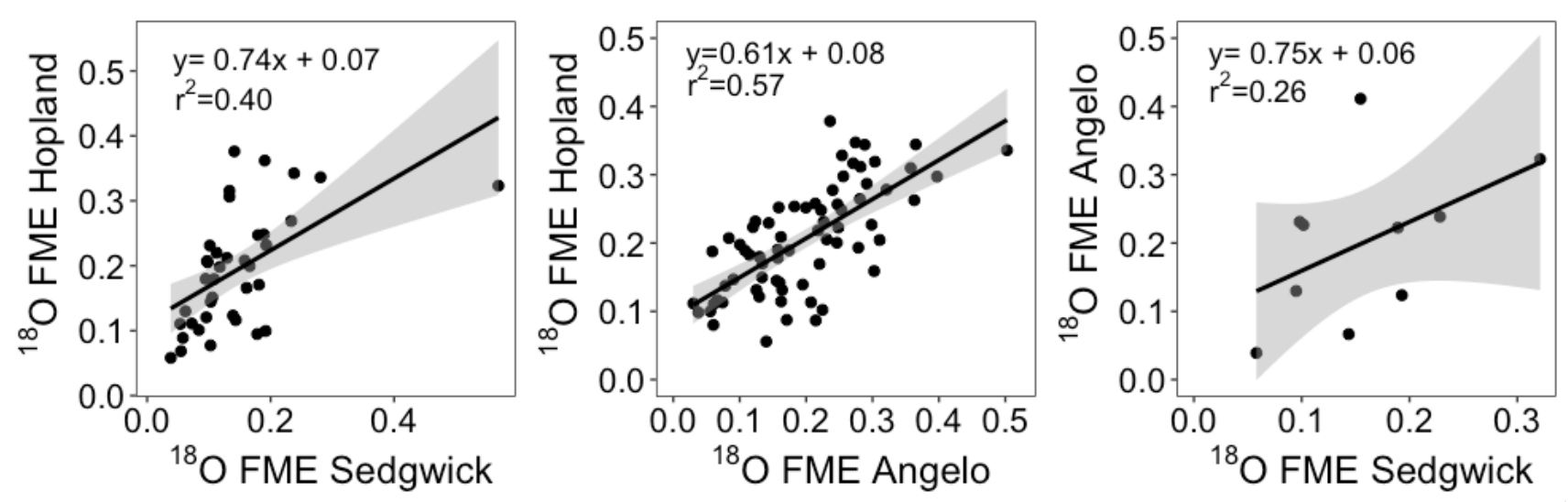

Figure 5 shows linear regressions (black line) of ${ }^{18} \mathrm{O}$ enrichment of microbial taxa co-occuring and in at least two sites. Shaded area shows 95\% C.I. for the regression. Regression results are presented in Supplementary Table 4. signals were observed in Angelo $(\lambda=0.82, \mathrm{p}<0.001, \mathrm{~K}=0.30, \mathrm{p}=0.001)$ and Hopland $(\lambda=0.85$, $\mathrm{p}<0.001, \mathrm{~K}=0.10, \mathrm{p}=0.004)$ than Sedgwick $(\lambda=0.68, \mathrm{p}<0.001, \mathrm{~K}=0.10, \mathrm{p}=0.010) . \mathrm{A}$

421 significant phylogenetic signal indicates that the growth rates of closely related taxa resemble

422 each other more than taxa drawn randomly from the same phylogenetic, however the values we 423 observed are somewhat lower than expected under Brownian motion evolution $(\lambda=1$ and $\mathrm{K}=1)$.

\section{Discussion}


We hypothesized that the convergence of environmental factors during the weeks

428 preceding sampling would result in growing microbial communities that were compositionally

429 more similar to each other than were total communities. In contrast to this expectation,

430 quantitative measures of between-site dissimilarity were equivalent for growing and total

431 communities (Figure 3). Heavy water quantitative stable isotope probing identifies growing

432 microbial populations (i.e. replicating DNA and synthesizing new biomass), and few studies

433 have compared the structure of growing communities to that of total communities. Some studies

434 have used RNA sequencing to compare the structure of the potentially metabolically active

435 community to that of the total community. These studies have found that potentially active

436 (RNA-based) communities can exhibit distinct biogeographic trends from total microbial

437 communities. For example, an assessment of forested ponds showed that distance decay

438 relationships were stronger for active communities than for total communities ${ }^{51}$. Additionally, a

439 study of arid and semiarid ecosystems found that total communities were more distinct from each

440 other than were active communities ${ }^{16}$. While the results from these studies suggest that

441 mechanisms such as dormancy and relic DNA may influence microbial biogeographic trends at

442 the regional scale, broader evidentiary support in the literature is lacking and the results from our

443 study do not support this finding. Using RNA sequencing to identify metabolically active

444 microbial populations in environmental samples has serious limitations and methodological

445 differences may contribute to the discrepancy between our results and the findings reported in

446 these studies ${ }^{18}$. Instead, our study showed that growing community composition strongly mirrors

447 that of the total community (Supplementary Figure 3).

449 Persistent Effect of Soil Moisture Limitation on Microbial Growth 
We hypothesized that a history of frequent prolonged periods of low soil water potential

451 at the driest site would result in lower microbial growth even when measured under controlled

452 laboratory conditions. Consistent with this expectation, community and phylum mean relative

453 growth rates were higher at the wet and intermediate sites, Hopland and Angelo, than at the

454 driest site, Sedgwick (Figure 4). This variation in growth rate does not appear to be driven by

455 edaphic parameters, as we would expect increasing substrate availability and higher pH levels to,

456 on average, facilitate faster bacterial growth rates ${ }^{52}$. Yet, substrate availability, here best

457 approximated by soil carbon, is highest in Sedgwick soils, the site in which we observed the

458 slowest growth on average. Further, we observed higher growth in the wetter and more acidic

459 soils, Hopland and Angelo.

460 We hypothesize that in our study, variation in microbial growth reflects a legacy effect of

461 the precipitation regime at the driest site. Similar variation in growth was documented for a

462 precipitation gradient in Texas, where microbial growth decreased with lower MAP when

463 measured under identical conditions in the $1 a b^{53}$. The literature directly testing the legacy effect

464 of low soil moisture on growth rate is inconsistent. While a number of short-term field and lab

465 experiments have found that historic exposure to drought reduces microbial growth rate, field

466 experiments operating on longer time scales ( $>10$ years) have failed to measure the same

467 effect ${ }^{8,54-57}$. The severity of moisture limitation may impact these findings, as the mentioned

468 long-term experiments featured more mild reductions in rainfall while the short-term

469 experiments featured more intense rainfall reductions.

A number of mechanisms may drive a legacy effect of low soil moisture on microbial

471 growth. Low levels of precipitation could influence growth rates indirectly by altering the quality

472 and quantity of plant carbon inputs during dry periods, reducing the availability of easily- 
473 assimilable substrates later in the year ${ }^{54}$. Slow microbial growth may also be driven by

474 physiological tradeoffs with traits that confer tolerance to water stress. In bacterial isolates,

475 moisture stress has been shown to drive a tradeoff between EPS production and the length of lag

476 phase, suggesting the relevance of growth rate in microbial acclimations to water stress ${ }^{58}$.

477 Such physiological adjustments to low soil water can occur through various mechanisms,

478 including shifts in microbial community composition ${ }^{9,59}$. Our findings suggest that the variability

479 in community and phylum mean growth rates across our sites may influenced by environmental

480 filtering at the driest site for slow-growing taxa that can withstand long periods of low soil water

481 potential. Consistent with current literature, we found evidence for a phylogenetic signal of

482 taxon-specific growth rates ${ }^{60,61}$. Additionally, we found that the growth rate of a bacterial taxon

483 in one site explained as much as $57 \%$ of the variation in that taxon's growth rate in another site

484 (Figure 5, Supplementary Table 4), illustrating the relevance of taxonomic identity to growth rate

485 in the environment. Within the community of microorganisms that were growing at the driest

486 site, most (155/197) were found growing at this site alone, and these ASVs that were uniquely

487 growing at Sedgwick demonstrated slower growth, on average, than taxa that occurred and grew

488 in at least one other site (Supplementary Figure 5). So, reduced microbial growth at the driest site

489 appears to be influenced predominantly by relatively slow-growing taxa that are unique to this

490 site. Lastly, the microbial families that actually grew faster in Sedgwick relative to the other sites

491 include taxa that have been described to have traits that would confer an advantage to surviving

492 dry spells. Certain members of the families Cystobacteraceae, Thermomonosporaceae, and

493 Rubrobacteraceae, can form spores ${ }^{62-64}$. The family Comamonadaceae includes the genus

494 variovorax which can accumulate polyhydroxyalkanoates for C storage within the cell and the

495 genome of a species within this same family (genus Ramlibacter) was found to have genes for 
496 carotenoid biosynthesis, EPS synthesis and hydrolysis, and trehalose synthesis ${ }^{62,65}$. We measured

497 microbial growth at the ASV level using qSIP and marker gene sequencing, and we thus lack

498 direct evidence regarding the traits and genomic potential of slow growing taxa at Sedgwick.

499 However future studies combining qSIP with metagenomic sequencing of DNA or RNA would

500 have the potential to reveal such patterns.

503 arrangement of growth rates among taxa from site to site (Figure 5), most likely reflects the

504 influence of genetic constraints on growth ${ }^{60}$. This finding suggests that the phenotype of in situ

505 growth rate for a given taxon spans a range constrained by its genetics and physiology,

506 constraints that persist across rainfall gradients, edaphic properties, and biological communities.

507 Gradients in climate and edaphic properties are powerful for testing controls over ecosystem

508 processes, including those processes driven by the phenotypes of microorganisms growing in the 509 wild. 

and Ryan Gini for assistance with field sampling and lab analyses. We thank John Bailey and Allison Smith at Hopland Research and Extension Center for help gathering meteorological data and the Oregon State University Soil Lab for chemical and physical soil analyses. We would like to thank Thomas Bristow, at the NASA Ames Research Center, for allowing access to his lab space for qXRD analysis. We would like to thank the Mambelli and Dawson Labs at UC Berkeley for stable isotope analysis. This research was supported by the U.S. Department of Energy, Office of Biological and Environmental Research, Genomic Science Program 'Microbes Persist' Scientific Focus Area (\#SCW1632) at Lawrence Livermore National Laboratory (LLNL) and a subcontract to Northern Arizona University. Work conducted at LLNL was conducted under the auspices of the US Department of Energy under Contract DE-AC52- 


\section{Literature Cited}

526 1. Dore, M. H. I. Climate change and changes in global precipitation patterns: What do we $527 \quad$ know? Environ. Int. 31, 1167-1181 (2005).

528 2. Schimel, J. P. Life in Dry Soils: Effects of Drought on Soil Microbial Communities and Processes. Annu. Rev. Ecol. Evol. Syst. 49, 409-432 (2018).

3. Barnard, R. L., Osborne, C. A. \& Firestone, M. K. Changing precipitation pattern alters soil microbial community response to wet-up under a Mediterranean-type climate. ISME J. 9, 946-957 (2015).

4. Cruz-Martínez, K. et al. Despite strong seasonal responses, soil microbial consortia are more resilient to long-term changes in rainfall than overlying grassland. ISME J. 3, 738-744 (2009).

5. Barnard, R. L., Blazewicz, S. J. \& Firestone, M. K. Rewetting of soil: revisiting the origin of soil CO2 emissions. Soil Biol. Biochem. 107819 (2020) doi:10.1016/j.soilbio.2020.107819.

6. Hawkes, C. V., Shinada, M. \& Kivlin, S. N. Historical climate legacies on soil respiration persist despite extreme changes in rainfall. Soil Biol. Biochem. 143, 107752 (2020).

540 7. Averill, C., Waring, B. G. \& Hawkes, C. V. Historical precipitation predictably alters the shape and magnitude of microbial functional response to soil moisture. Glob. Change Biol.

8. Nijs, E. A. de, Hicks, L. C., Leizeaga, A., Tietema, A. \& Rousk, J. Soil microbial moisture dependences and responses to drying-rewetting: The legacy of 18 years drought. Glob. Change Biol. 25, 1005-1015 (2019).

9. Evans, S. E. \& Wallenstein, M. D. Climate change alters ecological strategies of soil bacteria. Ecol. Lett. 17, 155-164 (2014). 
548 10. Malik, A. A. et al. Defining trait-based microbial strategies with consequences for soil

549 carbon cycling under climate change. ISME J. 14, 1-9 (2020).

550 11. Malik, A. A. et al. Drought and plant litter chemistry alter microbial gene expression and

551 metabolite production. ISME J. 1-12 (2020) doi:10.1038/s41396-020-0683-6.

552 12. Flemming, H. C. \& Wingender, J. Relevance of microbial extracellular polymeric substances

553 (EPSs)--Part I: Structural and ecological aspects. Water Sci. Technol. J. Int. Assoc. Water

$554 \quad$ Pollut. Res. 43, 1-8 (2001).

555 13. Sandhya, V. \& Ali, Sk. Z. The production of exopolysaccharide by Pseudomonas putida

556 GAP-P45 under various abiotic stress conditions and its role in soil aggregation.

$557 \quad$ Microbiology 84, 512-519 (2015).

558 14. Maestre, F. T. et al. Increasing aridity reduces soil microbial diversity and abundance in 559 global drylands. Proc. Natl. Acad. Sci. 112, 15684-15689 (2015).

560 15. Angel, R., Soares, M. I. M., Ungar, E. D. \& Gillor, O. Biogeography of soil archaea and 561 bacteria along a steep precipitation gradient. ISME J. 4, 553-563 (2010).

562 16. Angel, R., Pasternak, Z., Soares, M. I. M., Conrad, R. \& Gillor, O. Active and total 563 prokaryotic communities in dryland soils. FEMS Microbiol. Ecol. 86, 130-138 (2013).

564 17. Baubin, C. et al. Seasonal and spatial variability in total and active bacterial communities 565 from desert soil. Pedobiologia 74, 7-14 (2019).

566 18. Blazewicz, S. J., Barnard, R. L., Daly, R. A. \& Firestone, M. K. Evaluating rRNA as an 567 indicator of microbial activity in environmental communities: limitations and uses. ISME J. $568 \quad 7,2061-2068(2013)$. 
19. Power, M. E., Bouma-Gregson, K., Higgins, P. \& Carlson, S. M. The Thirsty Eel: Summer and Winter Flow Thresholds that Tilt the Eel River of Northwestern California from SalmonSupporting to Cyanobacterially Degraded States. Copeia 103, 200-211 (2015).

20. Sullivan, M. J. P., A.Thomsen, M. \& Suttle, K. B. Grassland responses to increased rainfall depend on the timescale of forcing. Glob. Change Biol. 22, 1655-1665 (2016).

574 21. Dietrich, W. The Problem of Channel Erosion into Bedrock. undefined (1992).

22. Berhe, A. A., Suttle, K. B., Burton, S. D. \& Banfield, J. F. Contingency in the direction and mechanics of soil organic matter responses to increased rainfall. Plant Soil 358, 371-383 (2012).

23. Fossum, C. et al. Belowground allocation and dynamics of recently fixed plant carbon in a California annual grassland soil. bioRxiv 2021.08.23.457405 (2021)

24. Homyak, P. M. et al. Effects of altered dry season length and plant inputs on soluble soil doi:10.1101/2021.08.23.457405.

25. Leitner, S. et al. Linking NO and N2O emission pulses with the mobilization of mineral and organic N upon rewetting dry soils. Soil Biol. Biochem. 115, 461-466 (2017).

26. Michael Barbour, Todd Keeler-Wolf, \& Allan A. Schoenherr. Terrestrial Vegetation of

$$
\text { California, 3rd Edition. vol. 3rd ed (University of California Press, 2007). }
$$
Meadow: a 10-year History of Recovery. Biol. Invasions 6, 245-254 (2004). measurements in water and calcium chloride that incorporate electrolyte concentration. Eur. J. Soil Sci. 62, 728-732 (2011). 
29. Eberl, D. D. User Guide to RockJock - A Program for Determining Quantitative Mineralogy from X-Ray Diffraction Data. http://pubs.er.usgs.gov/publication/ofr200378 (2003) doi:10.3133/ofr200378.

30. Stuiver, M. \& Polach, H. A. Discussion Reporting of 14C Data. Radiocarbon 19, 355-363 (1977).

31. Blazewicz, S. J., Schwartz, E. \& Firestone, M. K. Growth and death of bacteria and fungi underlie rainfall-induced carbon dioxide pulses from seasonally dried soil. Ecology $\mathbf{9 5}$, $1162-1172$.

32. Sieradzki, E. T. et al. Measurement Error and Resolution in Quantitative Stable Isotope Probing: Implications for Experimental Design. mSystems 5, (2020). Isotope Probing with 15N Achieved by Disentangling the Effects of Genome G+C Content and Isotope Enrichment on DNA Density. Appl. Environ. Microbiol. 73, 3189-3195 (2007).

34. Neufeld, J. D. et al. DNA stable-isotope probing. Nat. Protoc. 2, 860-866 (2007).

35. Parada, A. E., Needham, D. M. \& Fuhrman, J. A. Every base matters: assessing small subunit rRNA primers for marine microbiomes with mock communities, time series and global field samples. Environ. Microbiol. 18, 1403-1414 (2016). 806R gene primer greatly increases detection of SAR11 bacterioplankton. Aquat. Microb. Ecol. 75, 129-137 (2015). https://www.osti.gov/biblio/1241166 (2014). 
614 38. Callahan, B. J. et al. DADA2: High-resolution sample inference from Illumina amplicon

615 data. Nat. Methods 13, 581-583 (2016).

616 39. McMurdie, P. J. \& Holmes, S. phyloseq: An R Package for Reproducible Interactive

617 Analysis and Graphics of Microbiome Census Data. PLOS ONE 8, e61217 (2013).

618 40. Wang, Q., Garrity, G. M., Tiedje, J. M. \& Cole, J. R. Naive Bayesian Classifier for Rapid

619 Assignment of rRNA Sequences into the New Bacterial Taxonomy. Appl. Environ.

$620 \quad$ Microbiol. 73, 5261-5267 (2007).

621 41. MUSCLE: multiple sequence alignment with high accuracy and high throughput | Nucleic

622 Acids Research | Oxford Academic. https://academic.oup.com/nar/article/32/5/1792/2380623

623 (2020).

624 42. Price, M. N., Dehal, P. S. \& Arkin, A. P. FastTree 2 - Approximately Maximum-Likelihood

625 Trees for Large Alignments. PLOS ONE 5, e9490 (2010).

626 43. Hungate, B. A. et al. Quantitative Microbial Ecology through Stable Isotope Probing. Appl.

627 Environ. Microbiol. 81, 7570 (2015).

628 44. Papp, K., Hungate, B. A. \& Schwartz, E. Microbial rRNA Synthesis and Growth Compared

629 through Quantitative Stable Isotope Probing with $\mathrm{H}_{2}{ }^{18}$ O. Appl. Environ. Microbiol. 84,

$630 \quad \mathrm{e} 02441-17$ (2018).

631 45. Morrissey, E. M. et al. Bacterial carbon use plasticity, phylogenetic diversity and the priming

632 of soil organic matter. ISME J. 11, 1890-1899 (2017).

633 46. Pagel, M. Inferring the historical patterns of biological evolution. Nature 401, 877-884

634 (1999).

635 47. Blomberg, S. P., Garland, T. \& Ives, A. R. Testing for Phylogenetic Signal in Comparative

636 Data: Behavioral Traits Are More Labile. Evolution 57, 717-745 (2003). 
48. Janssen, S. et al. Phylogenetic Placement of Exact Amplicon Sequences Improves Associations with Clinical Information. mSystems 3, e00021-18.

49. Bolyen, E. et al. Reproducible, interactive, scalable and extensible microbiome data science

$$
\text { using QIIME 2. Nat. Biotechnol. 37, 852-857 (2019). }
$$

50. Voroney, R. P. \& Heck, R. J. Chapter 2 - The Soil Habitat. in Soil Microbiology, Ecology

$$
\text { and Biochemistry (Fourth Edition) (ed. Paul, E. A.) 15-39 (Academic Press, 2015). }
$$
doi:10.1016/B978-0-12-415955-6.00002-5.

51. Locey, K. J. et al. Dormancy dampens the microbial distance-decay relationship. Philos.

52. Rousk, J., Brookes, P. C. \& Bååth, E. Contrasting Soil pH Effects on Fungal and Bacterial

$$
\text { Growth Suggest Functional Redundancy in Carbon Mineralization. Appl. Environ. }
$$
Microbiol. 75, 1589-1596 (2009).

53. Leizeaga, A., Hicks, L. C., Manoharan, L., Hawkes, C. V. \& Rousk, J. Drought legacy affects microbial community trait distributions related to moisture along a savannah grassland precipitation gradient. J. Ecol. n/a, (2021).

54. Hicks, L. C., Rahman, M. M., Carnol, M., Verheyen, K. \& Rousk, J. The legacy of mixed planting and precipitation reduction treatments on soil microbial activity, biomass and community composition in a young tree plantation. Soil Biol. Biochem. 124, 227-235 (2018). legacy and tree species admixing on bacterial growth and respiration in a young forest soil upon drying and rewetting. Soil Biol. Biochem. 127, 148-155 (2018).

56. Meisner, A., Bååth, E. \& Rousk, J. Microbial growth responses upon rewetting soil dried for four days or one year. Soil Biol. Biochem. 66, 188-192 (2013). 
57. Rousk, J., Smith, A. R. \& Jones, D. L. Investigating the long-term legacy of drought and warming on the soil microbial community across five European shrubland ecosystems. Glob. Change Biol. 19, 3872-3884 (2013).

58. Lennon, J. T., Aanderud, Z. T., Lehmkuhl, B. K. \& Schoolmaster, D. R. Mapping the niche space of soil microorganisms using taxonomy and traits. Ecology 93, 1867-1879 (2012).

59. Allison, S. D. et al. Microbial abundance and composition influence litter decomposition response to environmental change. Ecology 94, 714-725 (2013).

60. Morrissey, E. M. et al. Evolutionary history constrains microbial traits across environmental variation. Nat. Ecol. Evol. 3, 1064-1069 (2019).

61. Morrissey, E. M. et al. Phylogenetic organization of bacterial activity. Isme J. 10, 2336 (2016).

62. The Family Cystobacteraceae | SpringerLink. https://link.springer.com/referenceworkentry/10.1007\%2F978-3-642-39044-9_304.

63. Kroppenstedt, R. M. \& Goodfellow, M. The Family Thermomonosporaceae: Actinocorallia, Actinomadura, Spirillospora and Thermomonospora. in The Prokaryotes: Volume 3: Archaea. Bacteria: Firmicutes, Actinomycetes (eds. Dworkin, M., Falkow, S., Rosenberg, E., Schleifer, K.-H. \& Stackebrandt, E.) 682-724 (Springer, 2006). doi:10.1007/0-387-30743- 
bioRxiv preprint doi: https://doi.org/10.1101/2021.12.06.471491; this version posted December 7, 2021. The copyright holder for this preprint (which was not certified by peer review) is the author/funder, who has granted bioRxiv a license to display the preprint in perpetuity. It is made available under aCC-BY 4.0 International license.

681 65. De Luca, G. et al. The Cyst-Dividing Bacterium Ramlibacter tataouinensis TTB310 Genome

682 Reveals a Well-Stocked Toolbox for Adaptation to a Desert Environment. PLoS ONE 6,

683 e23784 (2011).

684 